\title{
Green Synthesis and Characterization of Gold Nanoparticles: Study of Its Biological Mechanism in Human SUDHL-4 Cell Line
}

\author{
Umesh K. Parida' ${ }^{1}$, Susanta K. Biswal ${ }^{2}$, Birendra K. Bindhani1 ${ }^{*}$ \\ ${ }^{1}$ School of Biotechnology, KIIT University, Bhubaneswar, India \\ ${ }^{2}$ Department of Chemistry, Centurion University of Technology and Management, Bhubaneswar, India \\ Email: ${ }^{*}$ bbindhani2002@yahoo.com
}

Received 17 July 2014; revised 4 September 2014; accepted 22 September 2014

Copyright (C) 2014 by authors and Scientific Research Publishing Inc.

This work is licensed under the Creative Commons Attribution International License (CC BY). http://creativecommons.org/licenses/by/4.0/

\section{(c) (7) 0pen Access}

\begin{abstract}
In this investigation, the anticancer potentiality and biological mechanism of gold nanoparticles (AuNPs) was studied in SUDHL-4 cell line. Metallic AuNPs were prepared and stabilized with ethanol clove (Syzygium aromaticum) extract. The green synthesis of AuNPs was characterized and evaluated by UV-Visible Spectroscopic, X-ray Diffraction (XRD), Fourier Transform Infrared Spectroscopy (FTIR), Transmission electron microscopy (TEM), Dynamic Light Scattering (DLS) and biological activities using various biochemical assays. Green synthesis of AuNPs was confirmed by instrument method. The TEM images show polydisperse, mostly spherical AuNPs particles of $12-20 \mathrm{~nm}$. AuNPs were decreased the growth and viability of SU-DHL-4 cell line and increased the apoptosis. The treatments of SU-DHL-4 cells with AuNPs resulted in a moderate considerably increase in Reactive oxygen species (ROS) production. We measured apoptosis by Annexin-V/propidium iodide (PI) in the existence and nonexistence of the antioxidant $\mathrm{N}$-acetyl- $\mathrm{L}$ cysteine (NAC), the glutathione-depleting agent buthionine sulfoximine (BSO), or caspase inhibitors to determine the mechanism of cell death. AuNPs are unique potential anticancer agents that cause ROS-dependent apoptosis in SUDHL-4 cell line which was improved by depletion of glutathione (GHS) and inhibited by N-acetyl-L-cysteine on Z-VAD-FMK.
\end{abstract}

\section{Keywords}

Green Gold, Nanomedicine, Cell Line, Apoptosis, Oxidative Stress, ROS, Caspase

\footnotetext{
"Corresponding author.
}

How to cite this paper: Parida, U.K., Biswal, S.K. and Bindhani, B.K. (2014) Green Synthesis and Characterization of Gold Nanoparticles: Study of Its Biological Mechanism in Human SUDHL-4 Cell Line. Advances in Biological Chemistry, 4, 360-375. http://dx.doi.org/10.4236/abc.2014.46041 


\section{Introduction}

The past twenty years have seen a convergence of nano-engineering and biomedical research, giving rise to many new technologies and ideas about what can be achieved in medicine [1]-[4]. We have to accept that the present day nanotechnology is not something new, but it represents a series of technologies, some of which dating back to thousands of years [5]. It is only in recent years that these traditional practices are subjected to scientific scouting, understood and improved, at least in some instance. It is expected that the development in nanotechnology will lead to a new scientific revolution that could change the live and future of people [6]-[8].

The new or modern nanotechnology embraces all the medical clinical application, green synthesis technique and improvements made in the new nanotechnological process [9]-[11]. In recent years, synthesis of nanoparticles by using plants is gaining importance due to its effortlessness and eco-friendless [11]-[13]. Recently the biological synthesis of gold nanoparticles using many spices such as black seed (Nigella sativa), garlic, curcumin, Cinnamomum zeylanicum and clove (Syzygium aromaticum) has been reported [14]-[23]. The development of green metallic nanoparticles in present research is associated with field of applied microbiology, industrial and medicinal field [12] [13].

Biodegradable polymers like chitosan [24], cellulose [25] starch [26] and gum arabic [27]-[33] were also used as stabilizing agents in the preparation of AuNPs. Recently, lower concentrations of AuNPs have been explored by researchers for biomedical applications as it does not modify the chemical and photo-physical properties. Additionally, different AuNPs synthesized by different precursors must be stable under an in vitro environment that mimics in vivo conditions for any potential biomedical applications like potential treatment for cancer [34]-[37]. In addition, however, the detailed biochemical mechanism of action, regulatory protein cascades and efficacy against most cancer types are still unclear.

In this present day research programme, we desire to report the green synthesis of AuNPs using the ethanol clove (Syzygium aromaticum) extract and characterized. The potential effect of gold nanoparticles was studied in SUDHL-4 with some surprising results. There are several parameters that need to be considered for appropriate growth, proliferation and maintained of cell in culture.

\section{Materials and Methods}

All chemicals were used of analytical grade laboratory reagents. All solutions were prepared with deionised water obtained from a Millipore Milli-Q water system excluding media, which was prepared with distilled water. The chemicals were purchased from Nobel enterprises, used for synthesis of gold nanoparticles (AuNPs). A SUDHL-4 cell line was maintained in School of Biotechnology, KIIT University, Odisha, India. It was grown in medium (i.e., RPMI-1640) supplemented with $10 \%$ foetal calf serum in a humidified incubator at $37^{\circ} \mathrm{C}$ along with $5 \% \mathrm{CO}_{2}$. Collagen coated culture flasks were used when necessary and water was always used in demineralised form, $\mathrm{HAuCl}_{4}$ was purchased from Himedia. The compounds were dissolved at $10 \mathrm{mM}$ in $\mathrm{ddH}_{2} \mathrm{O}$ and DMSO as a stock solution, and then further diluted to desired concentrations for in vitro experiments. Cell Titer 96A Queous One Solution Cell proliferation Assay, Promega, 2’7’-dichlorofluo- rescein diacetate ( $\left.\mathrm{H}_{2} \mathrm{DCFDA}\right)$, Tetra-methyl-rhodamine (TMRE) (Invitrogen, Carlsbad, CA) were purchased from Biogenix, India.

\subsection{Preparation of Clove (Syzygium aromaticum) Ethanol}

Preparation of Extract: Dried fruits of clove (weight—50 g) (Figure 1(a)) were ground with the outer shells to obtain a coarse powder using an electric mixer. This was then taken in a muslin bag and subjected to Soxhlet extraction using ethanol (90\%) as solvent maintained at $60^{\circ} \mathrm{C}$ for 20 hours. The ethanol extract of Clove (Syzygium aromaticum) were made free from the solvent by using rotary evaporator. The yield obtained was $7 \%$ (w/w). Several scientific investigations are that clove (Syzygium aromaticum) contains high levels of antioxidant polyphenols, including euginol (Figure 1(b)), which is major constituent (72\%), have prevent the progress of various diseases. The eugenol compounds from ethanol extract were determined by GC/MS analyses.

\subsection{Synthesis of Gold Nanoparticles}

$1 \mathrm{mM} \mathrm{HAuCl}_{4}$ solution was added followed by the addition of ethanol clove (Syzygium aromaticum) extract (Figure 1(c)) solution with continued stirring. After changing the colour of the solution to reddish purple, 
(a)

(b)
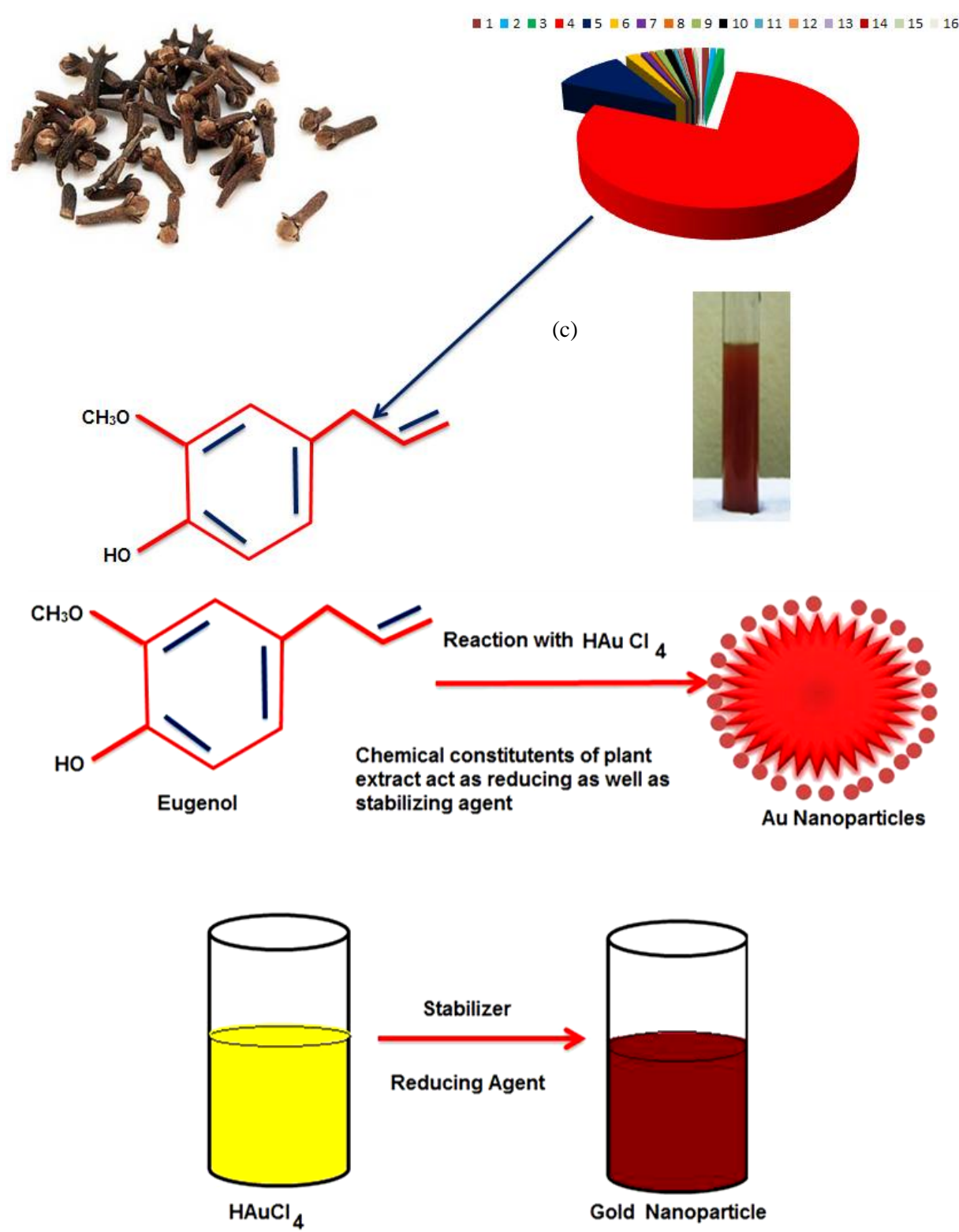

(d)

Figure 1. (a) Clove (Syzygium aromaticum); (b) Composition of various phytochemicals in clove; (c) Extract of clove (Syzygium aromaticum); (d) Schematically synthesis of gold nanoparticle.

continuous stirring was sustained for a minute without heating. The ratio of extract and auric acid solution in above procedure is 10:1, similarly 5:1 and 1:1 ratios were followed for optimization of protocol [18] (Figure 1(d)).

\section{Characterization}

\subsection{UV-Vis Spectroscopy}

The study of UV-vis spectroscopy measurements of the gold nano triangles were carried out using Shimadzu 1600 UV-vis Spectrophotometer (Kyoto, Japan). 


\subsection{X-Ray Diffraction}

It was done by using BEDE D-3 system with $\mathrm{Cu} \mathrm{K} \alpha$ radiation at a generator or voltage of $40 \mathrm{kV}$ and a generator current of $100 \mathrm{~mA}$. The samples were scanned from scanned from $2 \theta=1^{\circ}-100^{\circ}$ at a scanning rate of $2^{\circ} / \mathrm{min}$.

\subsection{Fourier Transform Infrared Spectroscopy Analysis}

A Perkin-Elmer Model of FTIR spectrophotometer, USA within the range of $4000-400 \mathrm{~cm}^{-1}$ was used for the samples analysis. Approximately, sample of $5 \mathrm{mg}$ was with $\mathrm{KBr}(100 \mathrm{mg})$ and condensed into pellet using hydraulic press. The KBr pellet methods were used for all FT-IR spectra analysis.

\subsection{Transmission Electron Microscopy}

It was performed on a JEOL model 1200EX instrument operated at an accelerating voltage at $80 \mathrm{kV}$.

\subsection{Zeta Size and Potential Analysis}

A Malvern Instrument, MAL 1037088, USA was used to determine the standard size of particle and zeta potential of nanoparticles. Disposable zeta cells measurement was carried with ultra-pure water at $25^{\circ} \mathrm{C}$ with a -50 $\mathrm{mV}$ latex standard calibrated frequently. The mean zeta potential was carried out using phase analysis light scattering technique.

\subsection{Cell Viability}

The cytotoxicity and viability effect of AuNPs against SUDHL-4 cell line were study by MTT assay. MTT based cytotoxic assay was carried out according to the instruction of kit providing by the manufacture. The absorbance was calculated at $490 \mathrm{~nm}$ using a micro plate reader. OD values were expressed as \% over the control group. Each data point was calculated in triplicate and all assays were performed at least three time.

\subsection{ROS Measurement}

The basic principle under lining the ROS accumulation in treated and untreated cells was measured by FACS, SU-DHL-4 cell line were incubated in $10 \mu \mathrm{m}$ 2' 7 '-dichlorofluorescein diacetate $\left(\mathrm{H}_{2} \mathrm{DCFDA}\right)$ for $30 \mathrm{~min}$ at $37^{\circ} \mathrm{C}$ in the dark. Cells were suspended in $1 \mathrm{ml}$ cold Propidium Iodide (PI) $(200 \mathrm{ng} / \mathrm{ml}) / \mathrm{PBS}$ for 5 minutes in order to test. Fluorescence intensity was read by flow cytometry using the Beckman counter EPICS XL-MCL Cytometer on the FL1 channel.

\subsection{Quantitation of Apoptosis}

After incubations and washing, $1 \times 106$ cells were marked with Annexin V-FITC and PI reagent in the binding buffer as per the instruction provided by invitrogen manufacturer. The detection of fluorescent signals of FITC and PI was carried out at $518 \mathrm{~nm}$ and $620 \mathrm{~nm}$ respectively by using Beckman coulter FACS machine (Beckman). For each analysis 30,000 events were recorded. The FCS Express V3 software (De Novo Software, Canada) and Excel (Microsoft) was used for calculation and analysis of results. The \% apoptosis was the sum of (Annexin V-FITC+/PI-) and (Annexin V-FITC+/PI+) cells.

\subsection{Western Blotting}

SDS-PAGEand Western blotting are two methods used to detect proteins. For this analysis, PBS was used for washing the cells followed by centrifugation and cell pellets treated with lysis buffer containing protease and phosphatase inhibitors. Bio-Rad protein assay kit (Bio-Rad, Hercules, CA) which was used to determine the concentrations of protein. Cell lysate was used for protein assay $25-50 \mu \mathrm{g}$ total protein samples were subjected to $12 \%$ SDS-PAGE electrophoresis. Proteins were electrophoretically transferred to a nitrocellulose membrane. Blocking of the membrane was carried out by $5 \% \mathrm{w} / \mathrm{v}$ BSA in TBST. Blocking can proceed at $4{ }^{\circ} \mathrm{C}$ with agitation with secondary antibody for $1 \mathrm{~h}$ at room temperature followed by washing thrice with TBST. Immune complexes were visualized by ECL kit. 


\subsection{Preparation of Mitochondrial and Cytosolic Fractions}

Different hours (0, 3, 18 and 24) were used for treated cells with AuNPs, NACand Z-VAD-FMK. Preparation of mitochondrial and cytosolic fractions was performed by using a mitochondria isolation kit for cultured cells as per the manufacturer's instructions. The mitochondrial pellet was re-suspended in sample buffer for SDS-gel electrophoresis and analyzed by western blotting for BAX antibody (Cell Signaling). COX IV (Cell Signaling) is used as an internal control for the mitochondrial fraction, and GAPDH (Chemicon) for the cytosolic fraction. Cytosolic fractions were also subjected to western blotting for BAX.

\subsection{Mitochondrial Membrane ( $\Delta \psi \mathrm{m})$ Measurement}

To make it final concentration of $250 \mathrm{~nm}$ by adding Tetramethylrhodamine (TMRE) (Invitrogen, Carlsbad, CA) just prior to the end of the incubation time. Further, cells were incubated at $37^{\circ} \mathrm{C}$ for 30 minutes. Then washed the cells in PBS twice and re-suspended in FACS buffer containing $20 \mathrm{~nm}$ TMRE and 2\% FBS. Fluorescence intensity was measured on the FL-2 channel of a flow cytometer. The FCS Express V3 software (De Novo Software, Canada) and Excel (Microsoft) was used for calculation and analysis of results.

\subsection{Statistics}

All results are expressed as means \pm SD. Comparisons among two values were performed by t-test. For various comparisons between diverse groups of data, the significant differences were determined by the Bonferroni method. Significance was defined at $\mathrm{p} \leq 0.05$.

\section{Results}

\subsection{UV-Visible Absorption Spectrum of AuNPs in Different Medium}

Figure 2(a) shows the, UV-visible absorption spectrum of the clove (Syzygium aromaticum) extract, AuNPs, AuNPs-RPMI cell culture medium. The characteristic absorbance peak at $391 \mathrm{~nm}, 546 \mathrm{~nm}$ and $559 \mathrm{~nm}$ (indicated by an arrow) is clearly observed in AuNPs in water and in cell culture medium. This data indicates that the biological media to be used for the cell culture studies did not change the stability of the AuNPs [14]. The symmetric peak indicates that the solution does not contain any aggregated particles. The stability of the AuNPs was determined by measuring the absorption spectrum at 24-h intervals for 30 days. The stability of nanoparticles is demonstrated in Figure 2(b) that shows the linear dependence of absorbance at $\lambda$ max on the concentration of gold in accordance with Beer-Lambert's Law. It was found that both $\lambda$ max and $\Delta$ are unaltered for clove-AuNP concentration ranging from $2.4-0.24 \mathrm{~nm}$ [27].

\subsection{Size of AuNPs Determinate by TEM}

Formed nanoparticles were characterized by absorption and TEM measurements. The average size of the spherical clove-AuNPs was estimated by TEM images and found to be 12 - $20 \mathrm{~nm}$ (Figure 2(c)). TEM analysis was carried out at 1.4 $\AA$ resolutions, which is optimal for NP size analysis [27]. Next, DLS analysis revealed that the formulated AuNPs had an average diameter of $18 \pm 1.2 \mathrm{~nm}$ (Figure 2(d)). The values clove- AuNPs are comparable with AuNPs of similar sizes synthesized by different methods in literature [38].

\subsection{Chemical Functional Group Determinate by FTIR}

FTIR analysis was performed to characterize any chemical changes that occurred during the synthesis of NPs. The FTIR data shows presence of following groups for ethanolic extract; $3129.13 \mathrm{~cm}^{-1}-\mathrm{OH}, 1645.43 \mathrm{~cm}^{-1}$ $-\mathrm{C}=\mathrm{C}, 1410.09 \mathrm{~cm}^{-1}-\mathrm{N}-\mathrm{H}, 923.99 \mathrm{~cm}^{-1}$-C-C, $1512.33 \mathrm{~cm}^{-1} \mathrm{C}_{6} \mathrm{H}_{6}, 1211.41 \mathrm{~cm}^{-1}$-C-O, 2106.43 -alkynes. From above data one can confirm the presence of eugenol in clove (Syzygium aromaticum) by phytochemical analysis and chemical test which is further reconfirmed by Rf value and FTIR in Figure 3(a) shows. Clove (Syzygium aromaticum) extract is after reaction with gold ions, this absorption band shows shift towards higher wave number with the loss in intensity [16] [17]. This observation indicates that eugenol molecules may be involved in the reduction of the surface of gold ion. It was observed that clove extract acts as a reducing and stabilizer to keep the nanoparticles segregated for a longer period. 


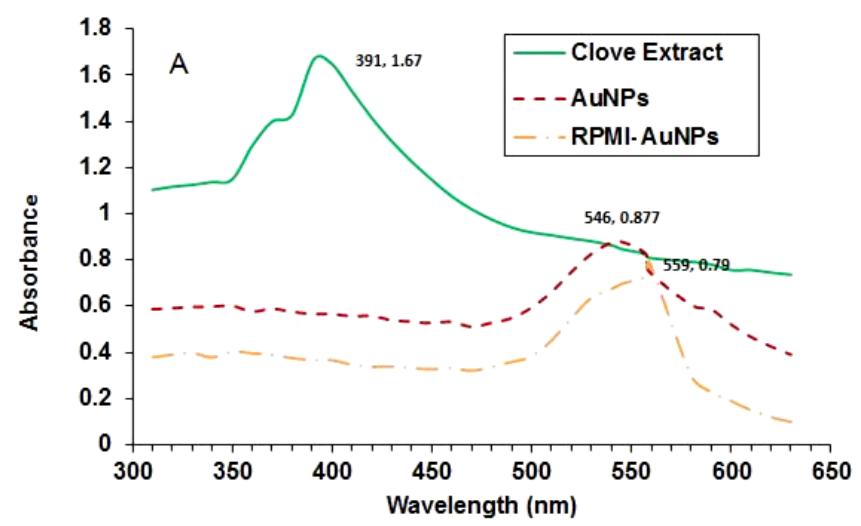

(a)

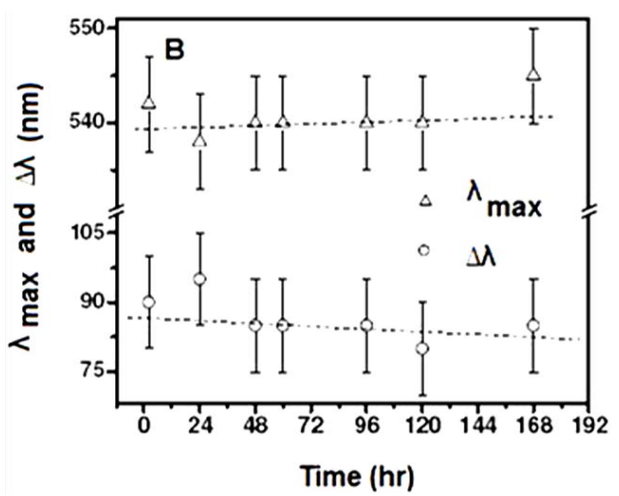

(b)

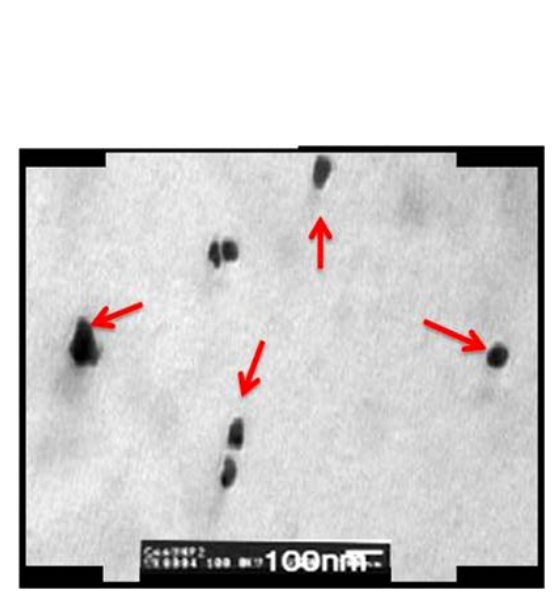

(c)

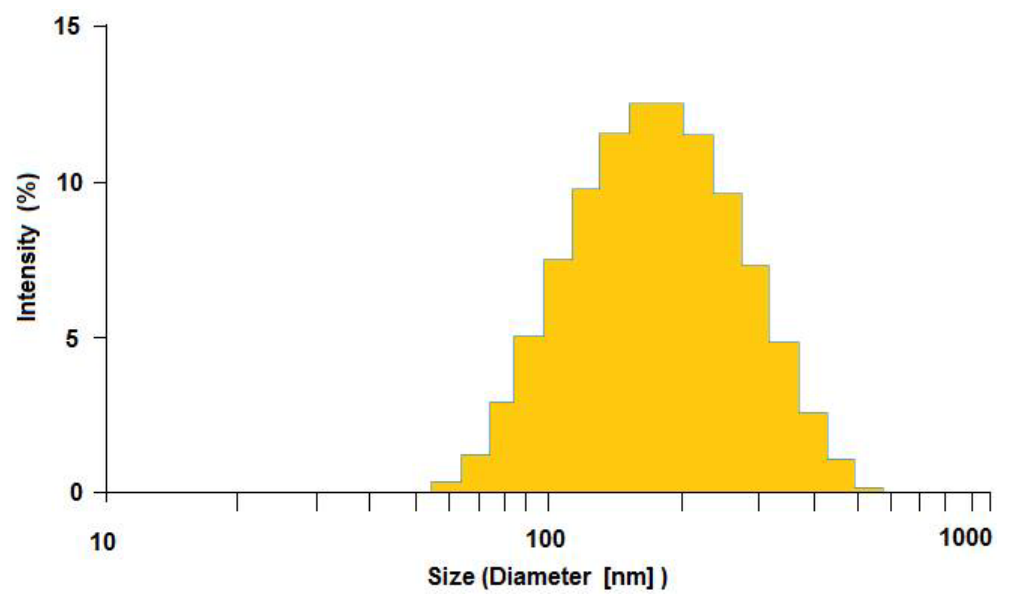

(d)

Figure 2. Synthesis and Stability of gold nanoparticles: (a) UV-visible spectrum of clove (Syzygium aromaticum) extract solution, colve-AuNPs, RPMI-AuNPs; (b) Stability of clove-AuNPs over time; (c) TEM of clove-AuNPs; (d) DLS of AuNP.

\subsection{XRD}

In Figure 3(b), the XRD pattern of AuNPs, in addition to these three peaks there are some unidentified peaks appeared in the XRD pattern. The distinguishing peaks corresponding to (111), (200), (220) of Au are located at $2 \theta=38.6^{\circ}, 42.43^{\circ}$ and $63.9^{\circ}$ respectively. The result indicates that the sample is composed of crystalline gold. The zeta-potential or net surface charge, of the Clove -AuNPs was also measured. The zeta-potential to be positive, with a value of $2.3 \pm 5 \mathrm{mV}$ in (Figure 3(c)) [16] [17] [38]. The neutral colve extract effectively coats the positively charged surface of the AuNPs, but the particles retain their positively charged characteristic. This data confirms that the clove-AuNPs are homogenously coated [27].

\subsection{Effect of AuNPs on Cell Proliferation of SUDHL-4 Cells}

To know the effect of AuNPs on the colony-forming ability of SU-DHL-4 cells which were treated with increasing concentration of clove extract, $\mathrm{HAuCl}_{4}$ and Clove-AuNPs separately for $72 \mathrm{~h}$. clove extract did not cause any significant growth inhibition in the cells at any concentration. $\mathrm{HAuCl}_{4}$ caused significant cell death in a concentration-dependent manner, with a maximum cell death of $50 \%$ observed at $200 \mu \mathrm{M}$. Interestingly, dosedependent cell death was noted, with AuNPs attaining maximum cell death of $84 \%$ at $200 \mu \mathrm{M}$ (Figure 4(a)). $\mathrm{IC}_{50}$ (achieved 50\% inhibition of cell viability) a broader range of concentrations were used in the same cell line, and the $\mathrm{IC}_{50}$ obtained was $150 \mu \mathrm{M}$ (Figure 4(b)). This data clearly indicates a decrease of cell survival in SUDHL-4 cells by means of AuNP exposure [39]-[41].

To further confirm the above results from the assay, a MTT cell viability assay was performed. Figure 5(a) illustrates the effect of clove extract, $\mathrm{HAuCl}_{4}$ and AuNPs on viability of SUDHL-4 cells by MTT assay. In 


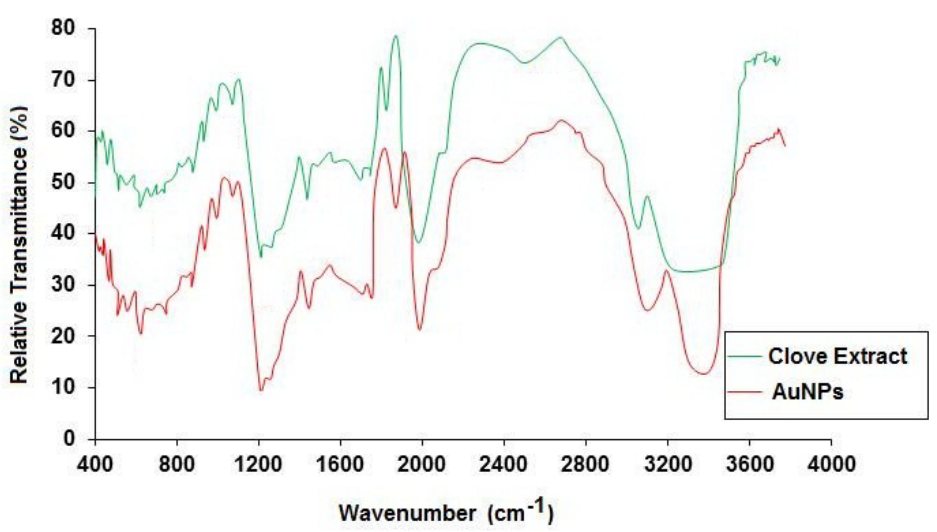

(a)

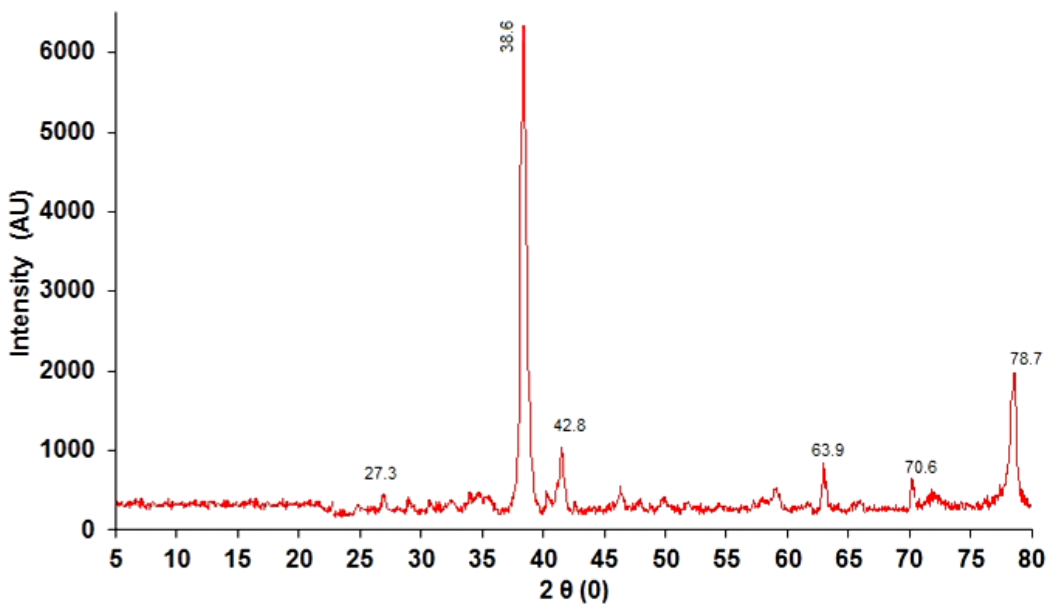

(b)

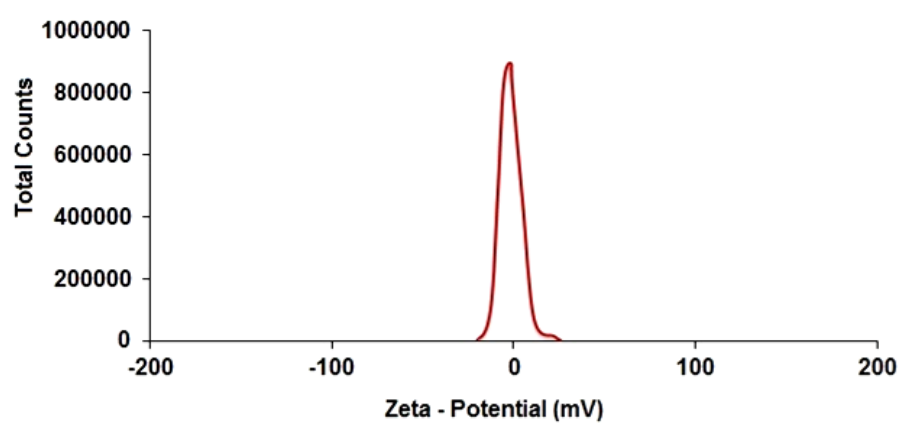

(c)

Figure 3. Characterization of clove-AuNPs-based nanoparticles: (a) FTIR of cove extract and clove-AuNPs; (b) XRD of AuNPs; (c) Measurement of zeta-potential (surface charge) of AuNPs.

agreement with the data from cell survival assay, clove extract did not show any killing effect on these cancer cells. $\mathrm{HAuCl}_{4}$ alone caused a drop in survival of $20 \%$. At the same concentration $(200 \mu \mathrm{M})$, AuNPs caused a dramatic drop in cell viability of more than $84 \%$ (Figure 5(a)) [40] [42].

To evaluate the effect of AuNPs on cell viability, we treated SUDHL-4 cells with 0 - $100 \mu \mathrm{M}$ for 24,48 , and $72 \mathrm{~h}$. AuNPs resulted in loss of cell viability in cell lines within a dose and time dependent manner (Figure 5(b)). $\mathrm{IC}_{50}$ (defined herein as that concentration that achieved 50\% inhibition of cell viability) at $48 \mathrm{~h}$ was 30 $\mu \mathrm{M}$ for SUDHL4. These data indicate that AuNPs inhibits cell viability in SUDHL-4 lymphoma cell lines in a dose and time-dependent manner and antiproliferative activities against SUDHL-4 cell. 


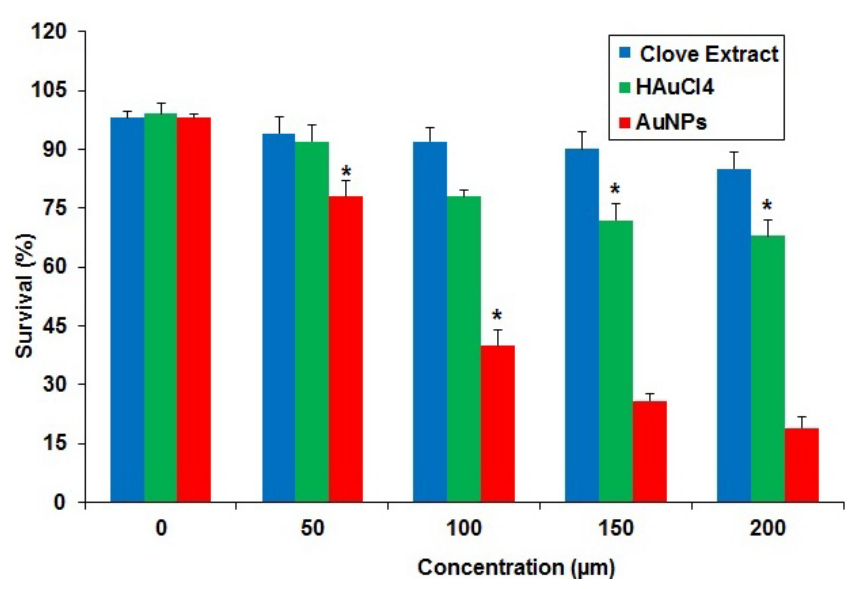

(a)

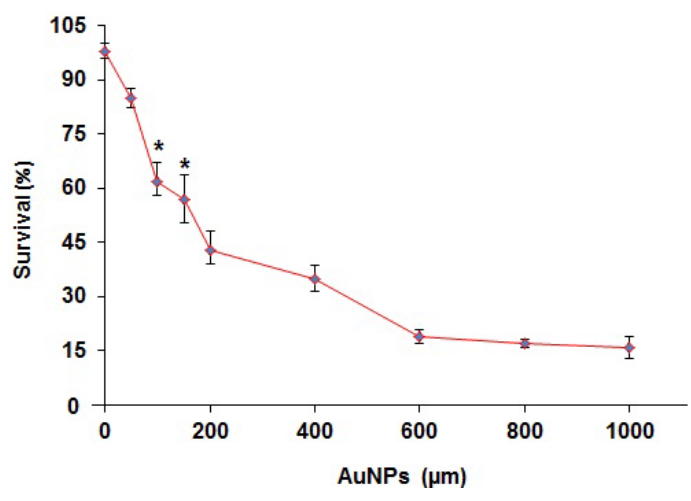

(b)

Figure 4. Clove-AuNPs decreased the colony-forming ability of SU-DHL-4 cells: (a) Treated cells with increasing concentrations of clove (Syzygium aromaticum), HAuCl4and AuNPs for $72 \mathrm{~h}$. The graph shows percentage survival against concentration; (b) Percentage survival of cell growth after treatment with increasing concentrations of AuNP for 72 h. Anchorage-dependent cell growth was decreased by AuNPs. ${ }^{*} \mathrm{p}<0.05$.

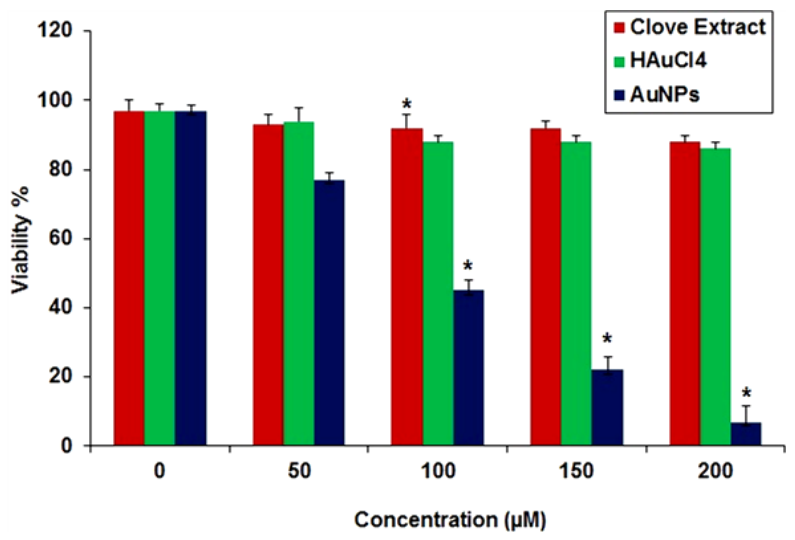

(a)

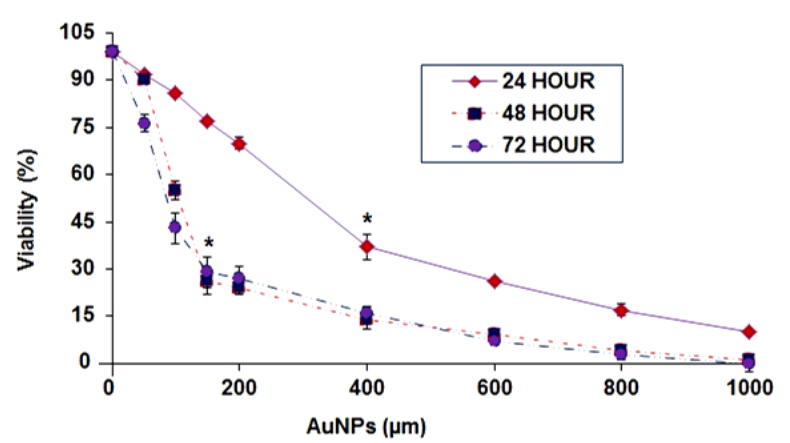

(b)

Figure 5. Cytotoxicity of gold nanoparticles in SU-DHL-4: (a) Treated cells with increasing concentrations of clove $\mathrm{HAUCl}_{4}$ and AuNPs for $48 \mathrm{~h}$ cell survival assay. The graph was plotted as percentage viability against AuNP concentration; (b) Percentage viability of cells after treatment by increasing concentrations of AuNPs for $24 \mathrm{~h}, 48 \mathrm{~h}$ and $72 \mathrm{~h}$.

\subsection{AuNPs Induces ROS Accumulation in SUDHL-4 Cell Line}

To examine whether AuNPs affects the oxidative function of the cell, we quantified ROS at different time points by measuring the fluorescent signal of DCF using fluorescence activated cell sorting (FACS). Cells treated with AuNPs were indicated dose and time period (Figure 6). We demonstrated significant $(\mathrm{p} \leq 0.05)$ ROS accumulation at $4 \mathrm{~h}$ for SUDHL-4 (Figure 6(a)). A shift to the right (red) indicates ROS accumulation. Figure 6(b) shows quantification of ROS accumulation in cell lines. The data shown represent percentage increase compared to control and represents the mean \pm standard deviation. Taken together, these data demonstrate that AuNPs induced ROS accumulation is dose and time-dependent in lymphoma cell lines [43].

The earliest intracellular events were occurred in apoptosis due to disruption of the mitochondrial membrane potential. It has been shown that AuNPs results in loss of MMP in a cell line. To investigate whether AuNPs affects $\Delta \psi$ min lymphoma cell lines, we measured $\Delta \psi \mathrm{m}$ in v SUDHL-4 (16 h) (Figure 6(c)). We start to see the change of $\Delta \psi$ mat 19 hours (Figure 6(c)). These data show that AuNPs results in dose-dependent loss of $\Delta \psi \mathrm{m}$.

\subsection{AuNPs Induces NAC-Reversible, Caspase-Dependent Apoptosis in SUDHL4 Cell Lines}

In order to find out whether AuNPs-induced loss of cell viability was related to apoptosis, we quantified apoptosis 


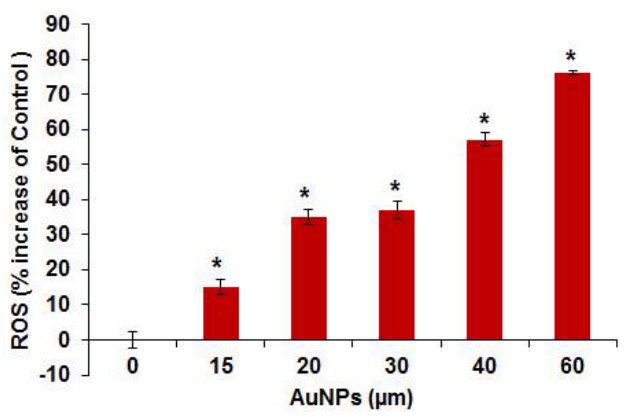

(a)

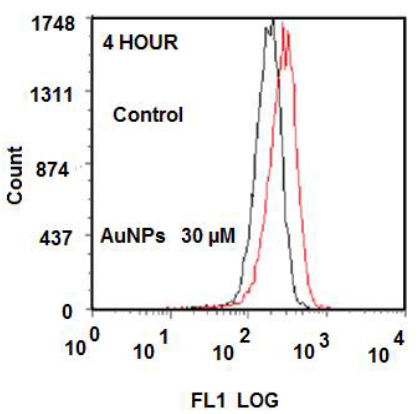

(b)

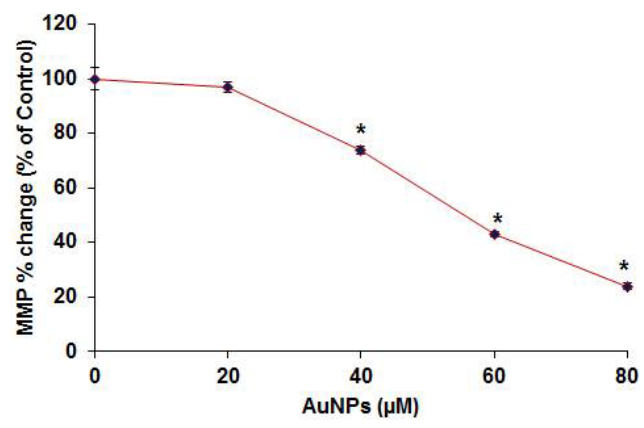

(c)

Figure 6. AuNPs-induced ROS accumulation and $\psi$ change in cell lines were dose dependent: (a) AuNPs induced ROS production in SUDHL4 cell lines; (b) Quantification of ROS accumulation in cell lines. The data shown represent percentage increase compared to control and represents the mean \pm standard deviation of experiments completed in triplicate. $*=p<0.05$ control vs. AuNPs; (c) Quantification of $\Delta \psi \mathrm{m}$ in cell lines. The data shown represent percentage decrease compared to control and represents the mean \pm standard deviation of experiments completed in triplicate. $(*=p \leq 0.05$, control vs. AuNPs).

by FACS after staining with Annexin V-FITC and PI (Figure 7). We found that AuNPs resulted in significant (p $<0.05$ ) dose-dependent apoptosis in SUDHL-4 at $48 \mathrm{~h}$. The AC50 (defined herein as that concentration that achieved 50\% apoptosis) was $30 \mu \mathrm{M}$ for SUDHL-4 at $48 \mathrm{~h}$ [44].

To determine if apoptosis was related to ROS, we co-incubated cells with the anti-oxidant NAC. In cell lines, NAC completely abrogated AuNPs-induced apoptosis (Figure 7(a)) $(\mathrm{p}<0.05)$. These data suggest that apoptosis was related to the cellular redox state, perhaps as a consequence of depletion of the endogenous antioxidant GSH, since NAC restores intracellular GSH. We further investigated the involvement of ROS in AuNPs induced apoptosis by pre-treating cells with the reduced GSH depleting agent BSO $(100 \mu \mathrm{M})$, and then added AuNPs or AuNPs and NAC at the indicated dose and time periods (Figure 7(b)). We found that BSO greatly enhanced AuNPs-induced apoptosis, and apoptosis was again completely inhibited by the antioxidant NAC. With the addition of BSO, the AC50 was significantly lower in cell lines (48 h, $20 \mathrm{uM}$ in SUDHL-4) compared with AuNPs alone. Next, to determine if AuNPs induced apoptosis was caspase-dependent, the caspase inhibitors Z-VADFMK, Ac-LEHD-CHO, Ac-IETD-CHO and Ac-DEVD-CHO, were pre incubated with SUDHL4 cell lines, then AuNPs added at the indicated doses and time periods (Figure 7(c)).

\subsection{AuNPs Induces PARP and Caspase Cleavage}

To further investigate the mechanism of apoptosis, we examined caspase activation and PARP cleavage by AuNPs using immune blotting (Figure 8). After $24 \mathrm{~h}$ of AuNPs exposure in SUDHL-4, we found that cleavage of PARP, caspase 3, and caspase 8 was dose dependent and completely inhibited by NAC (Figure 8). We also demonstrate time-dependent cleavage of PARP, caspase 8, caspase 9 and caspase 3 at $30 \mu \mathrm{M}$ in SUDHL-4 cells, at concentrations that have been shown to induce apoptosis (Figure 7). These data provide further evidence that AuNPs induced apoptosis is ROS and caspase-dependent, and may proceed by both intrinsic and extrinsic pathways [44]-[46]. 


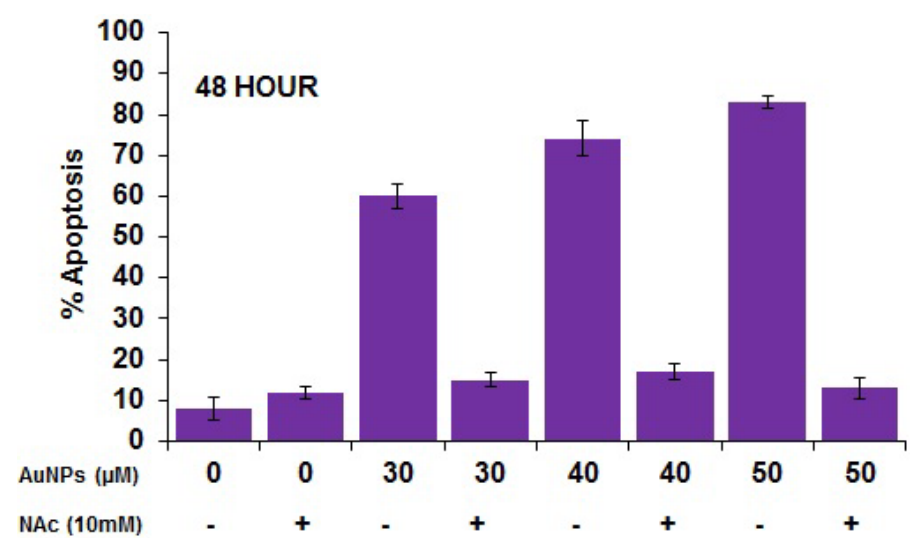

(a)

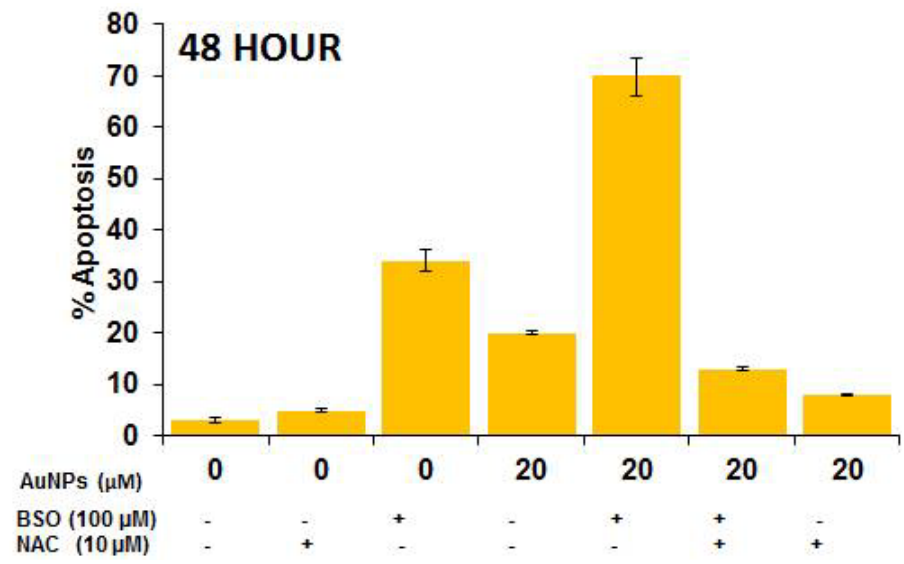

(b)

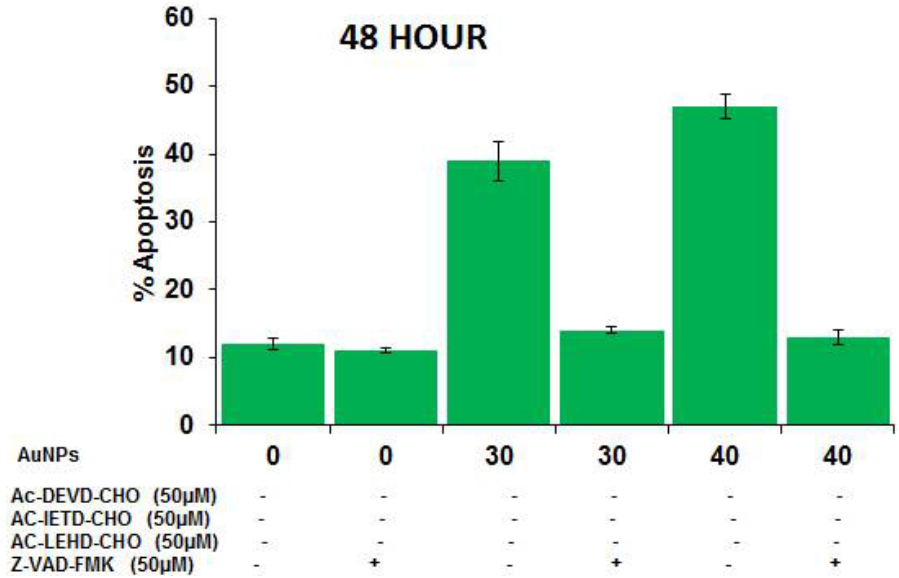

(c)

Figure 7. Dependence of apoptosis on ROS and caspases: AuNPs induced apoptosis was inhibited by the anti-oxidant NAC, or caspase inhibitors, but enhanced by BSO in SUDHL4 cell lines. Cells were treated with AuNPs, AuNPs + BSO, AuNPs + NAC, or AuNPs + caspase inhibitors at the indicated dose and time period. Annexin V-FITC and PI reagent were added and analyzed by FACS. (a) AuNPs induced apoptosis is dose-dependent. NAC completely inhibited AuNPs-induced apoptosis in cell $(\mathrm{p} \leq 0.05)$; (b) Cells were pre-treated with BSO $(100 \mu \mathrm{M})$ overnight, and then treated with AuNPs or AuNPs + NAC at the indicated dose and time period; (c) Pre-treated cells with 50 $\mu \mathrm{M}$ of the indicated caspase inhibitors (Ac-DEVD-CHO, Ac-IETD-CHO, Ac-LEHD-CHO or $\mathrm{Z}-\mathrm{VAD}-\mathrm{FMK}$ ) for $1 \mathrm{~h}$, and then AuNPs was added at the indicated concentrations for $48 \mathrm{~h}$. All of the caspase inhibitors significantly inhibited AuNPs-induced apoptosis ( $\mathrm{p} \leq 0.05)$. 


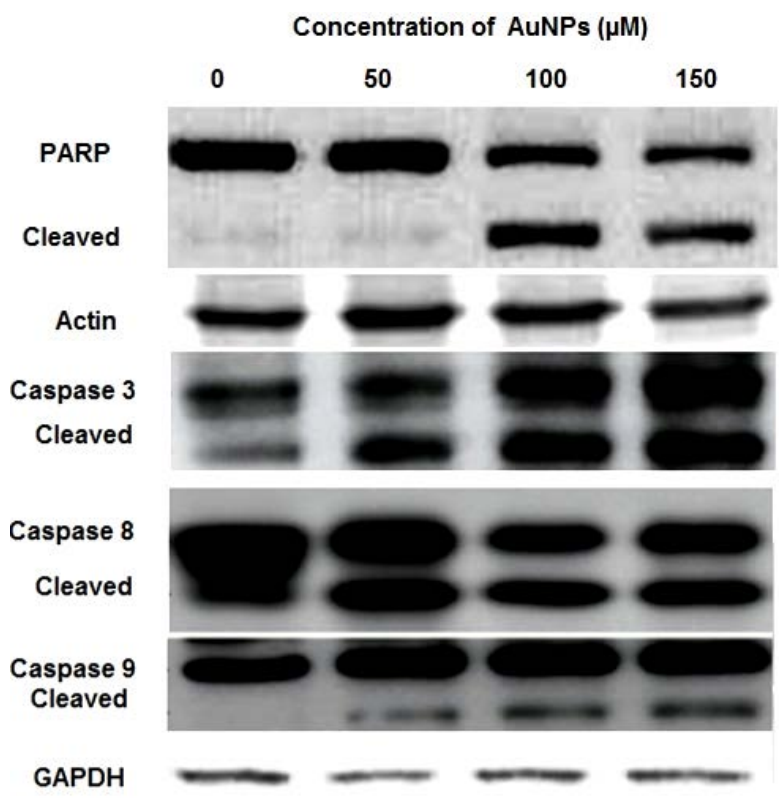

Figure 8. Mechanism of AuNPs-induced apoptosis: Treated cells with AuNPs in the existence or nonexistence of NAC $(10 \mathrm{mM})$ at the indicated dose and time period, and Western Blot were performed. AuNPs-induced cleavage of PARP, caspase 3 , caspase 8 , and caspase 9 was seen at $24 \mathrm{~h}$ (SUDHL-4).

\subsection{AuNPs-Mediated Apoptosis Depends on Mitochondrial Pathways}

In order to examine the participation of mitochondrial pathways in lymphoma cell death, we determined the role of BAX/BAK in AuNPs-induced apoptosis. BAX is a "multi domain" pro-apoptotic protein of the Bcl-2 family that is triggered by BID to undergo homo-oligomerization with BAK, resulting in discharge of cytochrome $\mathrm{c}$ from the mitochondria . To explore the role of Bcl-2 family proteins in AuNPs-induced apoptosis in lymphoma, however, we then investigated conformational change of BAX following mitochondrial translocation during apoptosis. Use of BAX monoclonal antibody, which exclusively binds the BAX protein with conformational change. AuNPs induced BAX conformational change in the SUDHL-4. These data demonstrate an increase of BAX fluorescent staining at 16 - $18 \mathrm{~h}$ in AuNPs treated cells, (Figure 9(a)). In addition, BAX conformational change was ROS and caspase-dependent, as treatment with NAC or pre-treatment with the pan caspase inhibitor Z-VAD-FMK eliminated the AuNPs induced BAX conformational change in cell lines (Figure 9(b)). These data indicate that AuNPs-induced apoptosis in cell lines depends in part on Bcl-2 family proteins and is ROSand caspase dependent. To further investigate mitochondrial events during AuNPs induced apoptosis, we extracted cytosolic and mitochondrial fractions for immune blotting. In the SUDHL-4, we found BAX accumulation in the mitochondrial fractions of cell lines by $3 \mathrm{~h}$, while BAX in the cytoplasm was reduced (Figure 9(b)). Thus AuNPs induces BAX conformational change and mitochondrial translocation from the cytoplasm in lymphoma, leading to cellular apoptosis [46].

\section{Discussion}

The knowledge gained from the experiments done in this research work opened new avenues to further research in the design and development of new methods to make gold nanoparticles with desired properties to aptly suit cancer diagnosis and therapy applications. Recently, scientist reported that AuNPs are capable of reducing tumor cell growth in vivo and in vitro [4] [5]. However, there is a lack of literature regarding the use of AuNPs as anticancer agents against cell line. Moreover the detailed biochemical mechanisms of the anticancer activity of AuNPs were not known. In the present report, we have shown for the first time that AuNPs exhibit anticancer activity in SU-DHL-4 cells and determined the mechanism of action. 

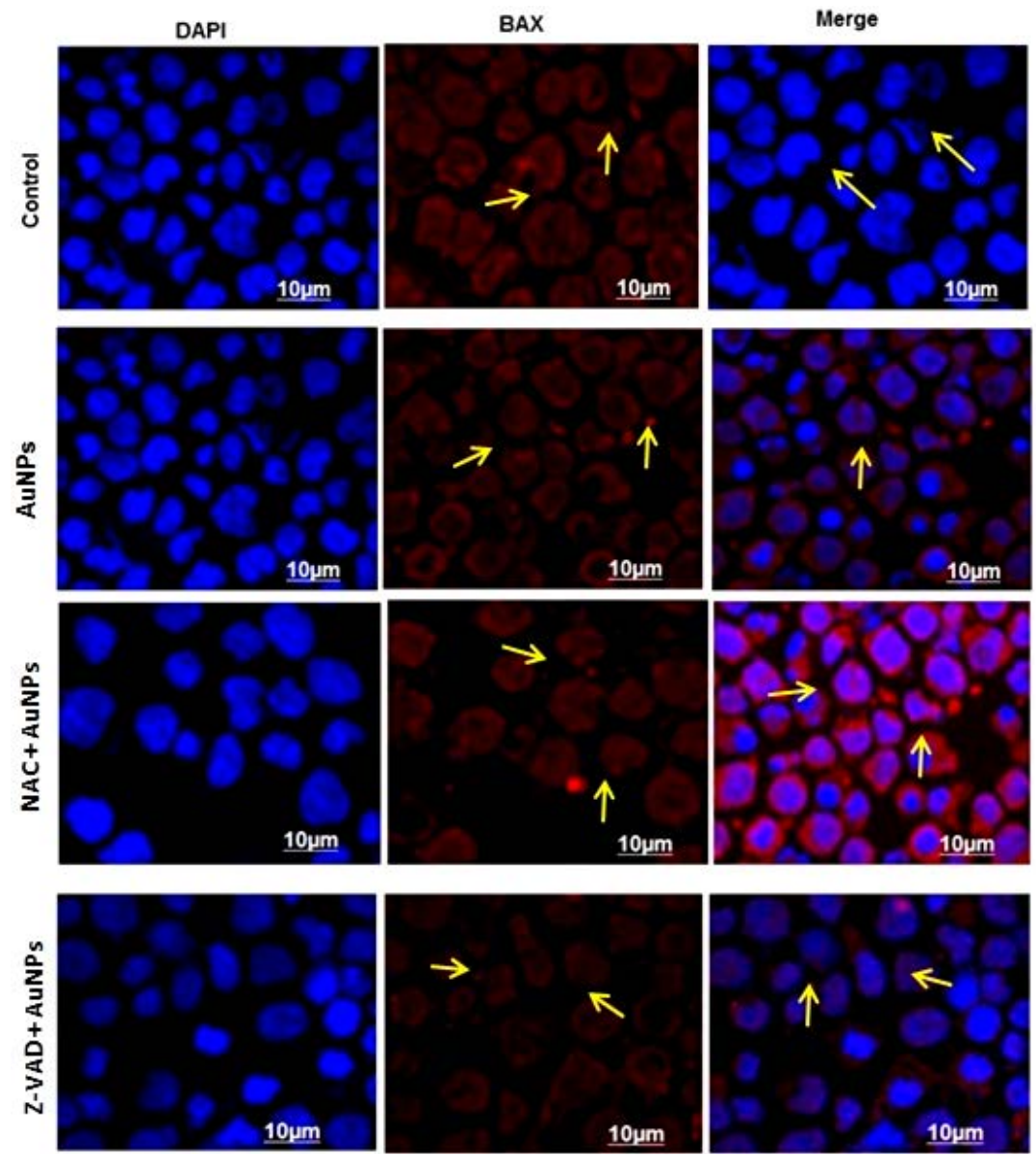

(a)

Concentration of AuNPs ( $\mu \mathrm{M})$

0

50

100

150

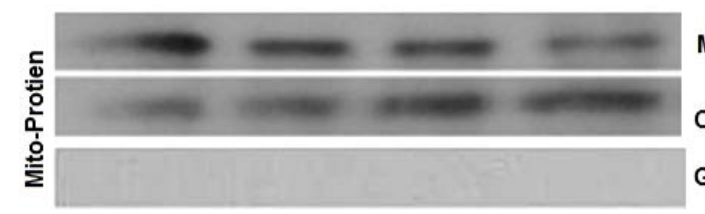

Mito BAX

COXIV

GAPDH

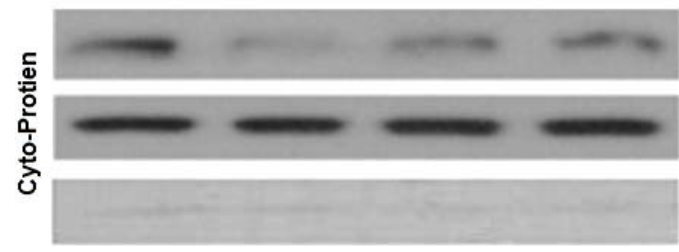

Cyto BAX

GAPDH

coxiv

(b)

Figure 9. AuNPs resulted in BAX conformational changes in SUDHL4 cell lines: (a) AuNPs induced BAX conformational changes in cell line; (b) All BAX conformational changes were blocked by NAC or Z-VAD-FMK. Mitochondrial and cytosolic fractions were separated as described in Materials and Methods and analyzed by western blotting for pro-apoptotic BAX protein. GAPDH and COX IV were used as internal controls for mitochondrial and cytosolic extracts, respectively. AuNPs-induced BAX translocation from cytoplasm to mitochondria was time-dependent. Abbreviations: Mito BAX, mitochondrial-related BAX; Cyto BAX, cytosolic-related BAX. 
For this study, we prepared a stable purified form of AuNPs using clove extract as a stabilizer agent, which showed remarkable stability and uniform distribution throughout the test period without any sign of aggregation and precipitation (Figure 2 and Figure 3). Thorough physiochemical characterization of the AuNPs revealed excellent average size and uniform surface charge. Cell viability experiments clearly indicated that AuNP treatment was toxic to SU-DHL-4 cells, while affecting SUDHL-4 cells to a much lesser degree (Figure 4 and Figure 5) [14]-[23].

We hypothesized that AuNPs might inhibit cell proliferation and cause apoptosis in lymphoma cell lines and in primary lymphoma cells by mechanisms that involved cellular redox systems, caspase activation, and mitochondrial pathways. Indeed, we found that the effects of AuNPs were dose and time related, and were accompanied by ROS generation (Figure 6). That ROS played an important role in apoptosis of lymphoma cell lines SUDHL-4 was demonstrated by near complete abrogation of apoptosis by the antioxidant NAC and by enhancement of apoptosis by the GSH depleting agent BSO. These observations were not restricted to cell lines [43].

We further postulated that AuNPs induced apoptosis in cell lines through intrinsic caspase pathways and mitochondrial regulation would be required. We also found that AuNPs induced $\Delta \psi \mathrm{m}$ change in SUDHL-4 (Figure 6(c)) [43].

We hypothesized that AuNPs, might inhibit cell proliferation and cause apoptosis in lymphoma cell lines and in primary lymphoma cells by mechanisms that involved cellular redox systems, caspase activation, and mitochondrial pathways. Indeed, we found that the effects of AuNPs, were dose and time related, and were accompanied by ROS generation (Figure 9). That ROS played an important role in apoptosis of lymphoma cell lines SUDHL4 was demonstrated by near complete abrogation of apoptosis by the antioxidant NAC and by enhancement of apoptosis by the GSH depleting agent BSO [43] [45] [46].

We found that AuNPs induced BAX conformational change in lymphoma cell lines (Figure 9). BAX conformational change is known to follow caspase 8 activation and is accompanied by pore formation in the outer mitochondrial membrane and precedes the release of cytochrome c from mitochondria, an important early step in mitochondrial mediated apoptosis [47]-[49]. We found no increase in total BAX, but found NAC-inhibitable conformational change in lymphoma cell lines. These data suggest the potential clinical relevance to lymphoma biology and suggest that clove-AuNPs may have antitumor activity with lymphoma.

Based on the above observations we have drawn a scheme of the mechanism of action and signaling cascade for AuNPs in SUDHL-4 cells (Figure 10). We have demonstrated that AuNPs, the active component of the AuNPs, causes cell death in lymphoma cell lines.

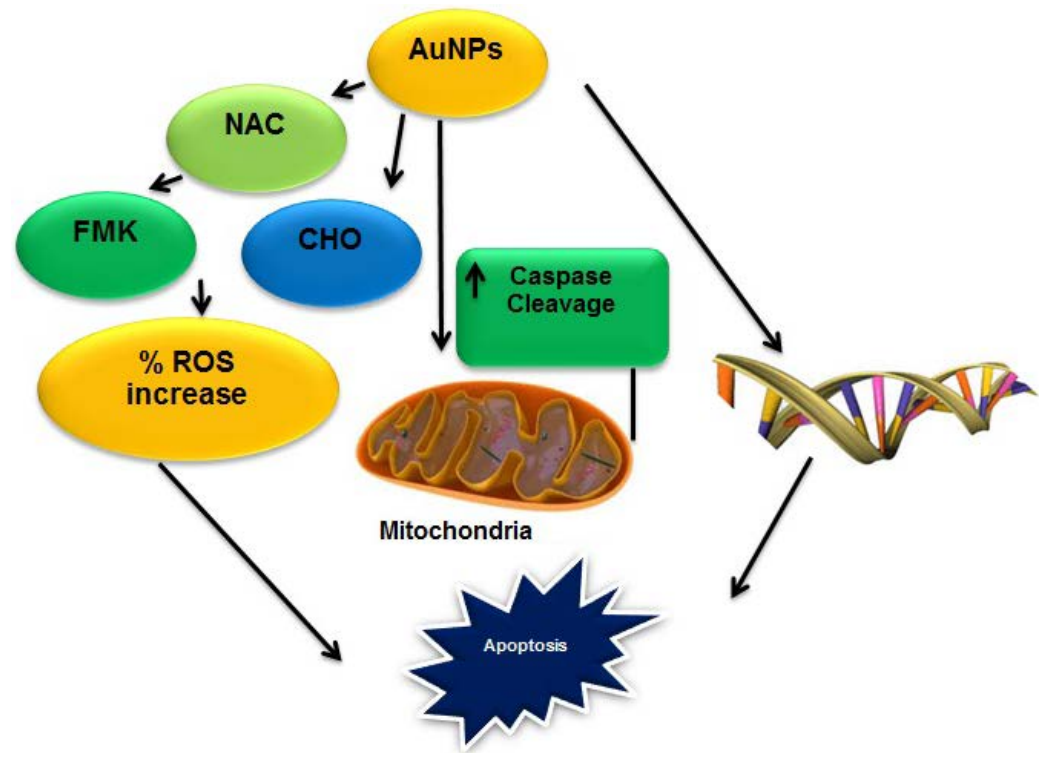

Figure 10. The mechanism of action of AuNPs. AuNPs cause apoptosis in SUDHL-4 cells by affecting multiple signaling cascades. The central mediator of AuNP-induced apoptosis in SU-DHL-4. 


\section{Conclusion}

The possibility of shape control of metallic nanoparticles was achieved at a level equal to chemical routes by purely green chemistry approach. These data were providing strong evidence that AuNPs should be studied further as potential novel anticancer agents to treat SUDHL-4 with an interesting mechanism of action.

\section{Acknowledgements}

The authors thank to Director, School of Biotechnology, KIIT University, Odisha India, HOD of Onco-Pathology, Acharya Harihara Regional Cancer Center, Odisha, India (AHRCC) and Subash Das, Kemwell Biopharma Pvt Ltd, Bangalore for their help in this research. Authors are also grateful to CIPET, Bhubaneswar and Chennai of India for their support.

\section{Financial Support}

This research work was partial supported by CSIR, Government of India.

\section{Competing Interests Disclosure}

We all authors declare that we have no competing interests. No writing support was utilized for this manuscript.

\section{References}

[1] Stylianou, A. and Talias, M.A. (2013) Nanotechnology-Supported THz Medical Imaging. F1000 Research, 2, 100.

[2] Barkalina, N., Charalambous, C., Jones, C. and Coward, K. (2014) Nanotechnology in Reproductive Medicine: Emerging Applications of Nanomaterials. Nanomedicine, 9634, 25-32.

[3] Tassel, P.R. (2013) Nanotechnology in Medicine: Nanofilm Biomaterials. Yale Journal of Biology and Medicine, 86, 527-536.

[4] Kim, T. and Hyeon, T. (2014) Applications of Inorganic Nanoparticles as Therapeutic Agents. Nanotechnology, 25, 012001. http://dx.doi.org/10.1088/0957-4484/25/1/012001

[5] Madani, S.Y., Mandel, A. and Seifalian, A.M. (2013) A Concise Review of Carbon Nanotube’s Toxicology. Nano Reviews, 4, 21521.

[6] Park, H., Hwang, M.P. and Lee, K.H. (2013) Immunomagnetic Nanoparticle-Based Assays for Detection of Biomarkers. International Journal of Nanomedicine, 8, 4543-4552.

[7] Tay, C.Y., Irvine, S.A., Boey, F.Y., Tan, L.P. and Venkatraman, S. (2011) Micro-/Nano-Engineered Cellular Responses for Soft Tissue Engineering and Biomedical Applications. Small, 7, 1361-1378. http://dx.doi.org/10.1002/smll.201100046.

[8] Rodríguez-Cabello, J.C., Martín, G.L.A., García-Arévalo, C., Arias, F.J. and Alonso, M. (2011) Emerging Applications of Multifunctional Elastin-Like Recombinamers. Nanomedicine, 6, 111-122. http://dx.doi.org/10.2217/nnm.10.141

[9] Sonvico, F., Dubernet, C., Colombo, P. and Couvreur, P. (2005) Metallic Colloid Nanotechnology, Applications in Diagnosis and Therapeutics. Current Pharmaceutical Design, 11, 2095-2105. http://www.ncbi.nlm.nih.gov/pubmed/15974961

[10] Baker, S., Rakshith, D.K., Kavitha, S., Santosh, P., Kavitha, H.U., Rao, Y. and Satish, S. (2013) Plants: Emerging as Nanofactories towards Facile Route in Synthesis of Nanoparticles. Bioimpacts, 3, 111-117.

[11] Nath, D. and Banerjee, P. (2013) Green Nanotechnology-A New Hope for Medical Biology. Environmental Toxicology and Pharmacology, 36, 997-1014. http://dx.doi.org/10.1016/j.etap.2013.09.002

[12] Das, R.K. and Brar, S.K. (2013) Plant Mediated Green Synthesis: Modified Approaches. Nanoscale, 5, 10155-10162. http://dx.doi.org/10.1039/c3nr02548a

[13] Rai, M. and Yadav, A. (2013) Plants as Potential Synthesiser of Precious Metal Nanoparticles: Progress and Prospects. IET Nanobiotechnology, 7, 117-124. http://dx.doi.org/10.1049/iet-nbt.2012.0031

[14] Seabra, A.B., Haddad, P. and Duran, N. (2012) Biogenic Synthesis of Nanostructured Iron Compounds: Applications and Perspectives. IET Nanobiotechnology, 7, 90-99. http://dx.doi.org/10.1049/iet-nbt.2012.0047

[15] Talat, M., Singh, A.K. and Srivastava, O.N. (2011) Optimization of Process Variables by Central Composite Design for the Immobilization of Urease Enzyme on Functionalized Gold Nanoparticles for Various Applications. Bioprocess and Biosystems Engineering, 34, 647-657. http://dx.doi.org/10.1007/s00449-011-0514-2 
[16] Raghunandan, D., Bedre, M.D., Basavaraja, S., Sawle, B., Manjunath, S.Y. and Venkataraman, A. (2010) Rapid Biosynthesis of Irregular Shaped Gold Nanoparticles from Macerated Aqueous Extracellular Dried Clove Buds Solution. Colloids and Surfaces B: Biointerfaces, 79, 235-240. http://dx.doi.org/10.1016/j.colsurfb.2010.04.003

[17] El-Batal, A.I., Hashem, A.A. and Abdelbaky, N.M. (2013) Gamma Radiation Mediated Green Synthesis of Gold Nanoparticles Using Fermented Soybean-Garlic Aqueous Extract and Their Antimicrobial Activity. SpringerPlus, 2, 129.

[18] Menon, D., Basanth, A., Retna kumari, A., Manzoor, K. and Nair, S.V. (2012) Green Synthesis of Biocompatible Goldnanocrystals with Tunable Surface Plasmon Resonance Using Garlic Phytochemicals. Journal of Biomedical Nanotechnology, 8, 901-911. http://dx.doi.org/10.1166/jbn.2012.1455

[19] Singh, D.K., Jagannathan, R., Khandelwal, P., Braham, A.P.M. and Poddar, P. (2013) In Situ Synthesis and Surface Functionalization of Gold Nanoparticles with Curcumin and Their Antioxidant Properties: An Experimental and Density Functional Theory Investigation. Nanoscale, 5, 1882-1893. http://dx.doi.org/10.1039/c2nr33776b

[20] Sneha, K., Sathishkumar, M., Lee, S.Y., Bae, M.A. and Yun, Y.S. (2011) Biosynthesis of Au Nanoparticles Using Cumin Seed Powder Extract. Journal of Nanoscience and Nanotechnology, 11, 1811-1814. http://dx.doi.org/10.1166/jnn.2011.3414

[21] Smitha, S.L. and Gopchandran, K.G. (2013) Surface Enhanced Raman Scattering, Antibacterial and Antifungal Active Triangular Gold Nanoparticles. Spectrochimica Acta Part A: Molecular and Biomolecular Spectroscopy, 102, 114-119. http://dx.doi.org/10.1016/j.saa.2012.09.055

[22] Chanda, N., Shukla, R., Zambre, A., Mekapothula, S., Kulkarni, R.R., Katti, K., Bhattacharyya, K., Fent, G.M., Casteel, S.W., Boote, E.J., Viator, J.A., Upendran, A., Kannan, R. and Katti, K.V. (2011) An Effective Strategy for the Synthesis of Biocompatible Gold Nanoparticles Using Cinnamon Phytochemicals for Phantom CT Imaging and Photoacoustic Detection of Cancerous Cells. Pharmaceutical Research, 28, 279-291. http://dx.doi.org/10.1007/s11095-010-0276-6

[23] Smitha, S.L., Philip, D. and Gopchandran, K.G. (2009) Green Synthesis of Gold Nanoparticles Using Cinnamomum zeylanicum Leaf Broth. Spectrochimica Acta Part A: Molecular and Biomolecular Spectroscopy, 74, 735-739. http://dx.doi.org/10.1016/j.saa.2009.08.007

[24] Fragoon, A., Li, J., Zhu, J. and Zhao, J. (2012) Biosynthesis of Controllable Size and Shape Gold Nanoparticles by Black Seed (Nigella sativa) Extract. Journal of Nanoscience and Nanotechnology, 12, 2337-2345. http://dx.doi.org/10.1166/jnn.2012.5739

[25] Huang, H. and Yang, X. (2004) Synthesis of Polysaccharide-Stabilized Gold and Silver Nanoparticles: A Green Method. Carbohydrate Research, 339, 2627-2631. http://dx.doi.org/10.1016/j.carres.2004.08.005

[26] You, J., Hu, H., Zhou, J., Zhang, L., Zhang, Y. and Kondo, T. (2013) Novel Cellulose Polyampholyte-Gold Nanoparticle-Based Colorimetric Competition Assay for the Detection of Cysteine and Mercury(II). Langmuir, 29, 5085-5092. http://dx.doi.org/10.1021/la3050913

[27] Shervani, Z. and Yamamoto, Y. (2011) Carbohydrate-Directed Synthesis of Silver and Goldnanoparticles: Effect of the Structure of Carbohydrates and Reducing Agents on the Size and Morphology of the Composites. Carbohydrate Research, 346, 651-658. http://dx.doi.org/10.1016/j.carres.2011.01.020

[28] Kattumuri, V., Katti, K., Bhaskaran, S., Boote, E.J., Casteel, S.W., Fent, G.M., Robertson, D.J., Chandrasekhar, M., Kannan, R. and Katti, K.V. (2007) Gum Arabic as a Phytochemical Construct for the Stabilization of Gold Nanoparticles: In Vivo Pharmacokinetics and X-Ray-Contrast-Imaging Studies. Small, 3, 333-341. http://dx.doi.org/10.1002/smll.200600427

[29] Ramakrishnan, A., Pandit, N., Badgujar, M., Bhaskar, C. and Rao, M. (2007) Encapsulation of Endoglucanase Using a Biopolymer Gum Arabic for Its Controlled Release. Bioresource Technology, 98, 368-372. http://dx.doi.org/10.1016/j.biortech.2005.12.020

[30] Leonor, S.J., Gómez, J.A., Kinoshita, A., Calandreli, I., Tfouni, E. and Baffa, O. (2013) ESR Spectroscopic Properties of Irradiated Gum Arabic. Food Chemistry, 141, 1860-1864. http://dx.doi.org/10.1016/j.foodchem.2013.04.095

[31] Effiong, U., Williams, D., Otto, W. and Anderson, W. (2004) Gum Arabic Surface Modified Magnetic Nanoparticles for Cancer Therapy. Proceedings of the IEEE 30th Annual Northeast Bioengineering Conference, Springfield, 17-18 April 2004, 243-244.

[32] Tiwari, S.B. and Amiji, M. (2006) A Review of Nanocarrier-Based CNS Delivery Systems. Current Drug Delivery, 3, 219-232. http://dx.doi.org/10.2174/156720106776359230

[33] Nallathamby, P.D. and Xu, X.H. (2010) Study of Cytotoxic and Therapeutic Effects of Stable and Purified Silver Nanoparticles on Tumor Cells. Nanoscale, 2, 942-952. http://dx.doi.org/10.1039/c0nr00080a

[34] Asharani, P.V., Lian, W.Y., Gong, Z. and Valiyaveettil, S. (2008) Toxicity of Silver Nanoparticles in Zebrafish Models. Nanotechnology, 19, Article ID: 255102. http://dx.doi.org/10.1088/0957-4484/19/25/255102

[35] Bunz, F., Hwang, P.M. and Torrance, C. (1999) Disruption of p53 in Human Cancer Cells Alters the Responses to 
Therapeutic Agents. Journal of Clinical Investigation, 104, 263-269. http://dx.doi.org/10.1172/JCI6863

[36] Li, J., Gupta, S. and Li, C. (2013) Research Perspectives: Gold Nanoparticles in Cancer Theranostics. Quantitative Imaging in Medicine and Surgery, 3, 284-291.

[37] Nossier, A.I., Eissa, S., Ismail, M.F., Hamdy, M.A. and Azzazy, H.M. (2014) Direct Detection of Hyaluronidase in Urine Using Cationic Gold Nanoparticles: A Potential Diagnostic Test for Bladder Cancer. Biosensors and Bioelectronics, 54, 7-14. http://dx.doi.org/10.1016/j.bios.2013.10.024

[38] Sánchez-Paradinas, S. and Pérez-Andrés, M. (2014) Enhanced Cytotoxic Activity of Bile Acid Cisplatin Derivatives by Conjugation with Gold Nanoparticles. Journal of Inorganic Biochemistry, 131, 8-11. http://dx.doi.org/10.1016/j.jinorgbio.2013.10.021

[39] Suman, T.Y. and Rajasree, S.R. (2014) The Green Syntheses of Gold Nanoparticles Using an Aqueous Root Extract of Morinda citrifolia L. Spectrochimica Acta Part A: Molecular and Biomolecular Spectroscopy, 118, 11-16. http://dx.doi.org/10.1016/j.saa.2013.08.066

[40] Leonard, K., Ahmmad, B., Okamura, H. and Kurawaki, J. (2011) In Situ Green Synthesis of Biocompatible Ginseng Capped Gold Nanoparticles with Remarkable Stability. Colloids and Surfaces B: Biointerfaces, 82, 391-396. http://dx.doi.org/10.1016/j.colsurfb.2010.09.020

[41] Green, D.E., Longtin, J.P. and Sitharaman, B. (2009) The Effect of Nanoparticle-Enhanced Photoacoustic Stimulation on Multipotent Marrow Stromal Cells. ACS Nano, 3, 2065-2072. http://dx.doi.org/10.1021/nn900434p

[42] Yang, S., Damiano, M.G. and Zhang, H. (2013) Biomimetic, Synthetic HDL Nanostructures for Lymphoma. Proceedings of the National Academy of Sciences of the United States of America, 110, 2511-2516. http://dx.doi.org/10.1073/pnas.1213657110

[43] Minai, L., Yeheskely-Hayon, D., Golan, L., Bisker, G., Dann, E.J. and Yelin, D. (2012) Optical Nano Manipulations of Malignant Cells: Controlled Cell Damage and Fusion. Small, 8, 1732-1739. http://dx.doi.org/10.1002/smll.201102304

[44] Minai, L., Yeheskely-Hayon, D. and Yelin, D. (2013) High Levels of Reactive Oxygen Species in Gold Nanoparticle-Targeted Cancer Cells Following Femtosecond Pulse Irradiation. Scientific Reports, 3, Article No. 2146. http://dx.doi.org/10.1038/srep02146

[45] Qu, X., Yao, C., Wang, J., Li, Z. and Zhang, Z. (2012) Anti-CD30-Targeted Gold Nanoparticles for Photothermal Therapy of L-428 Hodgkin's Cell. International Journal of Nanomedicine, 7, 6095-6103. http://dx.doi.org/10.2147/IJN.S37212

[46] Lin, Y.W., Chen, Y.C., Wang, C.W., Chen, W.T., Liu, C.M., Chen, C.Y. and Chang, H.T. (2013) Gold Nanosponges: Green Synthesis, Characterization and Cytotoxicity. Journal of Nanoscience and Nanotechnology, 13, 6566-6574. http://dx.doi.org/10.1166/jnn.2013.7770

[47] Shi, Y., Yi, C., Zhang, Z., Zhang, H., Li, M., Yang, M. and Jiang, Q. (2013) Peptide-Bridged Assembly of Hybrid Nanomaterial and Its Application for Caspase-3 Detection. ACS Applied Materials Interfaces, 5, 6494-6501. http://dx.doi.org/10.1021/am401935y

[48] Jun, Y.-W., Sheikholeslami, S., Hostetter, D.R., Tajon, C., Craik, C.S. and Alivisatos, A.P. (2009) Continuous Imaging of Plasmon Rulers in Live Cells Reveals Early-Stage Caspase-3 Activation at the Single-Molecule Level. Proceedings of the National Academy of Sciences of the United States of America, 106, 17735-17740. http://dx.doi.org/10.1073/pnas.0907367106

[49] Patra, H.K., Banerjee, S., Chaudhuri, U., Lahiri, P. and Dasgupta, A.K. (2007) Cell Selective Response to Gold Nanoparticles. Nanomedicine: Nanotechnology, Biology and Medicine, 3, 111-119. http://dx.doi.org/10.1016/j.nano.2007.03.005 
Scientific Research Publishing (SCIRP) is one of the largest Open Access journal publishers. It is currently publishing more than 200 open access, online, peer-reviewed journals covering a wide range of academic disciplines. SCIRP serves the worldwide academic communities and contributes to the progress and application of science with its publication.

Other selected journals from SCIRP are listed as below. Submit your manuscript to us via either submit@scirp.org or Online Submission Portal.
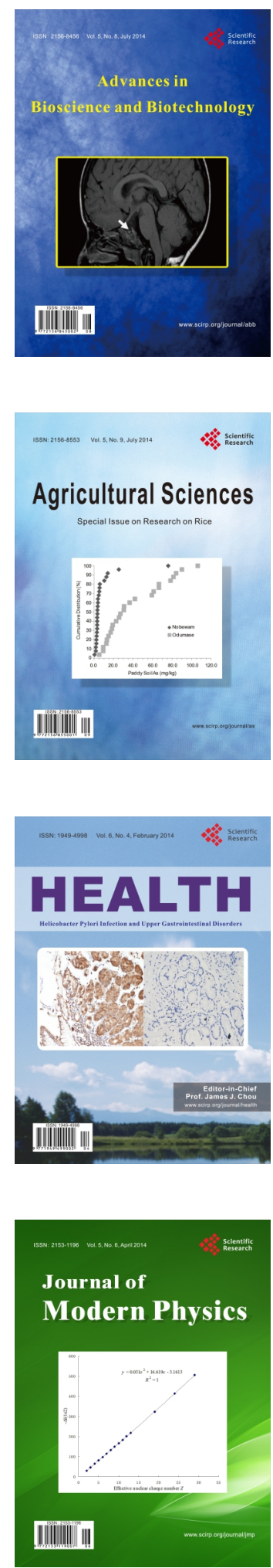
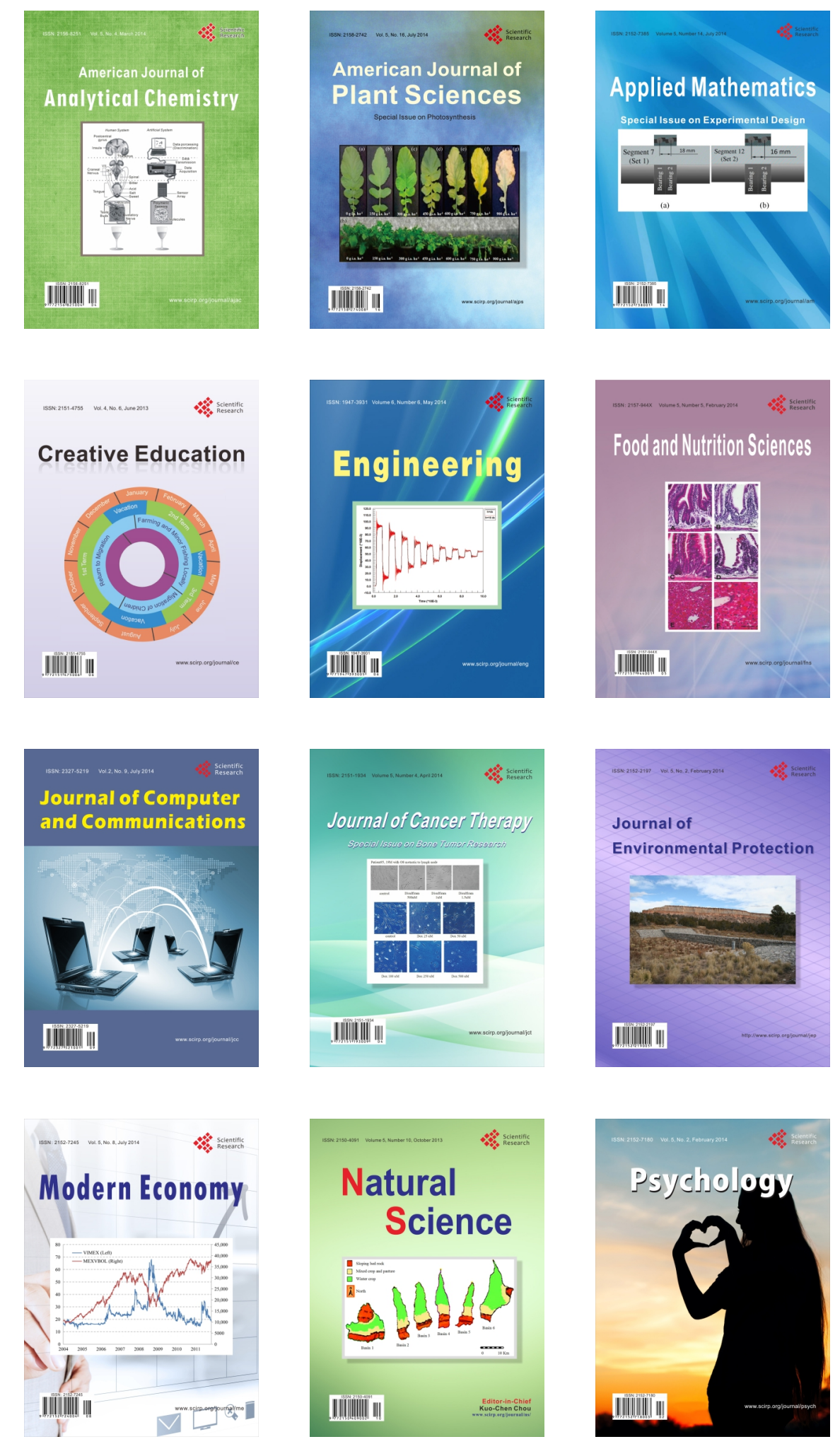